\title{
Residential Mortgage Price Risk and Market Returns of Publicly Listed Mortgage Originators in Kenya
}

\author{
Mwikamba Tumaini Mutugi ${ }^{1} \quad$ Prof. Willy Muturi ${ }^{2} \quad$ Dr. Oluoch Oluoch ${ }^{3}$ \\ 1. PhD Finance Candidate, Jomo Kenyatta University of Agriculture and Technology, Kenya \\ 2. Professor: School of Business and Entrepreneurship, Jomo Kenyatta University of Agriculture and \\ Technology, Kenya \\ 3. Senior Lecturer: School of Business and Entrepreneurship, Jomo Kenyatta University of Agriculture and \\ Technology, Kenya
}

\begin{abstract}
Interest rates play a critical role for mortgage originating firms. Interest rate volatility significant influences mortgage uptake among other factors. Empirical literature focus on the relationship between interest rate volatility, and financial performance, and stock return. However, literature is inconclusive and inconsistent with reference to the relationship between residential mortgage price risk and market returns for mortgage originating firms in Kenya. Consequently, the overall objective of this study was to ascertain the effect of residential mortgage price risk on market returns of publicly listed mortgage originators in Kenya. The Loanable Funds Theory of Interest and Efficient Market Hypothesis model were utilized as the theoretical foundation of the study. The study adopted a descriptive form of research design. A census was conducted on the target population - 11 publicly listed mortgage originators in Kenya. The study sourced its secondary data from the following sources: Central Bank of Kenya bank supervision reports, and the Nairobi Securities Exchange. Data was collected for the period between 2009 and 2019. The statistical software STATA was utilized to analyze data collected. A panel data regression model was used to draw inference from the data collected. The mean and standard deviation findings for residential mortgage interest rate as 0.2193 and 0.11195 respectively. The findings reveal a significant negative effect of residential mortgage price risk on market returns of publicly listed mortgage originators in Kenya. It is recommended that mortgage originators use derivative instruments and competitive interest rates to hedge against fluctuations in interest rates.
\end{abstract}

Keywords: Price Risk, Interest Rates, Mortgage, Mortgage Originators, Residential Mortgage.

DOI: $10.7176 /$ RJFA/12-10-10

Publication date:May $31^{\text {st }} 2021$

\section{Introduction}

Interest rate is a proportion of principal charged by lender for money lent (Shiller, 2012; Agenor \& Montiel, 2015). The main component in the cost of a loan is the interest rate. To borrowers, interest rates are a cost of borrowing. In addition, interest rate fluctuations have a direct influence on borrower loan cost. However, interest rates are a source of income to the lender. Interest rates have a direct influence on savings and investment (Agenor \& Montiel, 2015). It is for this reason that Central Banks - regulators - manage interest rates through various monetary policy instruments to attain idyllic economic growth and development. Revenues for financial institutions can be classified into interest income and non-interest income (Molyneux \& Vallelado, 2008). According to Molyneux and Vallelado (2008), interest income is one of the major source of revenues for lending financial institutions.

Numerous studies have been conducted with reference to relationship between interest rate and bank financial performance. For instance, Minny and Gormus (2017) argue that there is a positive relationship between interest rate volatility and the performance of financial institutions. In the same vein, Muharrami (2015) postulate that volatility of interest rates significantly influences banks' equity, assets, and net income. According to Muharrami (2015), a bank's profit margin declines when interest expenses increase more rapidly than interest revenues. In Kenya, Juma and Atheru (2018) argue that there is a positive significant relationship between bank return on assets and interest rate.

Empirical literature further explores on the relationship between interest rate and stock return. For instance, Nick (2016) argues that changes in interest rates influence the earnings for financial institutions. Consequently, stock prices are affected by interest rate volatility. Similarly, Mbulawa (2015) argues that in Zimbabwe there is a relationship between stock market performance and interest rates. In Ghana, Coleman (2008) reveals that inflation rate, exchange rate and interest rate significantly influence stock market performance. Oyedele (2017) argues that a rise in interest rates will negatively affect stock market performance. Oyedele (2017) attributes this to the fact that a rise in interest rate will result in better financial institution performance. In contrast, Avallone (2017) notes that current world stock prices are rising despite global instability, stock market correction, and rising interest rates. These findings suggest that the relationship between interest rates and stock market performance may not be definite as outlined in empirical literature.

Interest rate fluctuations result in price risk for mortgage originating firms. Price risk is the adverse effect in 
the value of the mortgage commitment as a consequence of changes and fluctuations in mortgage rates (Shiller, 2012). Interest rates play a critical role for mortgage originating firms. For instance, Kigomo (2016) identifies the following as the factors which significantly influence mortgage uptake in Kenya: income, interest rates, credit risk, and mortgage costs. Similarly, Macharia and Wanyoike (2016) echo similar sentiments. In the same vein, Njiru and Moronge (2013) identify the following as the most significant factors that influence mortgage industry growth: accessibility to mortgage facilities, and volatility of interest rates. Other factors identified by the study include: government regulations and policies, and default risk.

Mortgages play a critical role in real estate development (Brener, 2020). Through mortgage finance, developers get access to finances needed to fund their development projects. Mortgages form a critical part of capital markets both for developed and developing markets (Barth, 2009). Kenya's mortgage market is therefore not an exception. Kenya's mortgage market can be described as one which is steadily growing. The World Bank and the Central Bank of Kenya (CBK) carried out a Baseline Survey in 2010 whose findings revealed that Kenya's mortgage market had tripled from Ksh. 19 billion in 2006 to Ksh. 61 billion in 2010 (World Bank, 2011). Similarly, CBK (2018), the value of the mortgage loans increased by 0.76 percent to Ksh. 224.9 billion in 2018 from Ksh. 223.2 billion in the year 2017. Kenya's mortgage to Gross Domestic Product (GDP) ratio stood at 2.7 percent for the year 2017 (Muiruri, 2019). According to CBK (2018), 33 banks out of 43 banks in Kenya were offering mortgage products in the year 2018. In addition, 76.1 percent of mortgage lending in the year 2018 was done by six banks.

\subsection{Statement of the Problem}

From the year 2010, the market returns for mortgage originating banks in Kenya has been inconsistent. For instance, Omondi (2016) conducted a study in 2015 whose findings revealed that six of the eleven listed mortgage originating banks at the Nairobi Securities Exchange (NSE) had experienced a decline in their earnings per share (EPS). Similarly, Ngugi (2018) argues that the mortgage originating banks listed at the NSE experienced a decline of one percent in EPS in the year 2017. Ngugi (2018) attributed this to a number of factors including interest rate capping.

Numerous studies - Ahmed et al. (2018), Obegi and Oluoch (2019), Lagat and Okendo (2016), and Macharia (2013) - have focused on the relationship between interest rates and financial performance of commercial banks in Kenya. In addition, empirical findings are inconclusive and inconsistent with reference to the relationship between interest rates and stock returns. For instance, Amarasinghe (2015) reveals that there is a negative significant relationship between interest rate and stock price. In contrast, Vaz et al. (2015) reveal that there is a positive significant relationship between interest rate fluctuations and bank stock returns. Consequently, this study sought to shed light on the influence of residential mortgage price risk on market returns of public listed mortgage originators in Kenya.

According to Mutegi et al. (2019), the annual housing demand within the Kenyan market stands at 250,000 units. This demand creates numerous opportunities for the growth and development of the mortgage sector. However, Kenya's mortgage to GDP ratio stood at 2.7 percent for the year 2017 (Muiruri, 2019). There are approximately 20,000 mortgage accounts in Kenya despite Kenya's population of approximately 40 million (Mwaniki, 2013). Muiruri (2019) argues that Kenyans perceive mortgages to be expensive as a result of variable interests. For this reason, they prefer to alternative sources of finance for funding home ownership.

\subsection{Research Objective}

To ascertain the effect of residential mortgage price risk on market returns of publicly listed mortgage originators in Kenya.

\subsection{Statistical Hypothesis}

Residential mortgage price risk has no significant effect on market returns of publicly listed mortgage originators in Kenya.

\section{Literature Review}

\subsection{Theoretical Review}

The theoretical foundation for the study was based on two theories: The Loanable Funds Theory of Interest and Efficient Market Hypothesis.

\subsubsection{The Loanable Funds Theory of Interest}

The loanable funds theory of interest was propagated by Knut Wicksell (Wicksell, 1936). The theory states that interest rate is determined by the demand for and supply of loanable funds (Burton \& Brown, 2009). According to Burton and Brown (2009), loanable funds constitute all forms credits for instance savings deposits, bonds, and loans. The theory is based on the following assumptions: First, the integration of markets for loanable funds which is furthermore characterized by the perfect mobility of funds. Second, there is perfect competition. The theory 
further assumes that interest rate does not interact with other macro variables.

Based on these assumptions, Kenyan mortgage originators can source for cheaper long term finance from the global financial system which offers cheaper interest rates as compared to the local financial system. In addition, the originators can negotiate with global financial institutions for better rates and repayment terms. In this light, Kenyan mortgage originators can offer diversified mortgage rates and terms. In addition, interest rates are liberalized in Kenya and therefore mortgage firms can compete through interest rate diversification techniques. This is will in turn positively influence profitability and market return. In this case, the loanable funds theory of interest was used in analyzing its applicability by Kenyan mortgage originators in managing price risk.

Akenga, Olang and Galo (2015) cite the assumptions of the loanable funds theory as the basis for its limitations. For instance, the theory assumes the perfect mobility of funds as one of its assumptions. However, there are various regulations and restrictions that govern the transfer of funds from one country to another. For this reason, raising of funds from another country may pose a challenge for mortgage originators.

\subsubsection{Efficient Market Hypothesis}

The Efficient Market Hypothesis (EMH) theory was developed by Eugene Fama (Fama, 1970). The theory postulates that stocks trade at their fair value in security markets which makes it impossible for investors to either sell stocks for inflated prices or purchase undervalued stocks (Burton \& Shah, 2013). Consequently, the only technique an investor can earn higher returns is through investing in riskier investments. However, there are various reasons which can make the EMH incorrect. For instance, investors view information differently and may therefore have different stock valuations (Elton et al., 2009). Another reason is that stocks take time to reflect new information and thus investors who act on this information first can take advantage of it. Finally, stock prices can be affected by human error or human emotions (Burton \& Shah, 2013). In addition, investors can benefit from market anomalies.

According to Elton et al. (2009), there are three variants of EMH: strong, semi-strong, and weak. For the strong form of $\mathrm{EMH}$, the hypothesis suggests that share prices reflect both insider information and public information and thus investors cannot expect to earn superior returns (Burton \& Shah, 2013). For semi-strong $\mathrm{EMH}$, the hypothesis claims that share prices reflect all publicly information available - for example present financial statements - and therefore investors cannot use the financial statements of a company to forecast future price movements and secure higher returns (Elton et al., 2009). For weak form, EMH propagates that current share prices reflect past information. Consequently investors should not outperform the market using 'past' information. In this case, the assumptions of EMH were utilized in the determination of market returns for mortgage originators in Kenya. The study assumed that the market returns for the mortgage originators were fairly priced. This implied that share prices for the 11 publicly listed mortgage originators were not underpriced or overpriced.

\subsection{Empirical Review}

Liow and Huang (2006) conducted a study which sought to determine the effect of interest rate volatility on the stock returns of Asian property firms. The study sourced for secondary data from property stock indexes for the period 1987 to 2003. The findings of their study revealed that property stocks are sensitive to short and long-term interest rate changes. Similarly, Tran (2013) carried out a study whose findings revealed that interest rate volatility significantly influences bank stock returns and performance. In particular, long-term interest rates and returns of bank ordinary stocks are correlated positively. In the same vein, Dhanani et al. (2008) argues that UK banks invest a substantial proportion of their resources in managing interest rate risk. For instance, derivatives are one of the strategies UK banks use to reduce interest rate risk. By adequately managing interest rate risk, commercial banks are able to ensure shareholder wealth maximization (Dhanani et al., 2008).

Oluwaseyi, Islam, Yusoff and Rahman (2019) carried out a study which sought to determine the influence of interest rate risk and liquidity risk on firm value. The sample for the study comprised of 63 banks in 5 Association of Southeast Asian Nations (ASEAN) countries. Secondary data for the period was collected from the year 2009 to 2017. Study findings revealed that there is a significant positive effect between loan to deposits ratio and firm value. In addition, findings revealed that there is a significant negative effect between interest rate risk and firm value. Oluwaseyi et al. (2019) argue that there is a significant negative effect between liquidity risk and return on equity. It is imperative for financial institutions to develop mitigation measures against these risks which significantly impact on their financial performance (Oluwaseyi et al., 2019).

Similarly, Meng and Deng (2013) carried out a study in China which sought to determine the relationship between foreign exchange, interest rate and bank stock returns. The study population comprised of 14 banks listed at Shenzhen and Shanghai stock exchanges. The study adopted a GARCH model to draw inference from the data collected. The findings of the study reveal that there is an insignificant relationship between interest rate fluctuations and stock returns. However, study findings revealed a significant relationship between foreign exchange fluctuations and stock returns.

Amarasinghe (2015) conducted a study which sought to determine the relationship between interest rate and stock price. The case study for the investigation was Colombo Stock Exchange. Secondary data was sourced from 
the all share price index from the period between the year 2007 and 2013 . The study utilized a regression model to draw inference from the secondary data collected. The findings of the study revealed that there is a negative significant relationship between interest rate and stock price.

Vaz, Ariff and Brooks (2008) carried out a study in Australia which sought to determine the relationship between bank stock returns and interest rate fluctuations. The study collected secondary data from the 1990 to 2005. The study collected secondary data from eleven banks listed at the Australian Stock Exchange. The findings of the study revealed a positive significant relationship between interest rate fluctuations and bank stock returns.

Ahmed et al. (2018) conducted a study in Pakistan which sought to determine the influence of fluctuations of interest rates on the financial performance of banks. The study sourced its data from 20 banks with the highest market share operating in Pakistan for the period between 2007 and 2014. Regression and correlation analysis was utilized draw inference from the data collected. The findings for the study revealed that there is a negative relationship between interest rate fluctuations and bank profitability. However, findings revealed a positive relationship between loans and advances and bank profitability. However, the study does not assess the impact of interest rate fluctuations on bank market return.

Ndung'u (2012) also carried out a study in Kenya whose objective was to determine the influence of interest rate volatility on stock returns. The study utilized data from the NSE and the CBK. The study revealed interest rates do affect stock market performance. For instance, a rise in interest rates will result in people investing more in saving bank accounts rather than the stock market. Thus, Ndung'u (2012) recommends that the monetary policy committee need to be keen with determining the interest because it can adversely affect the performance of the Nairobi Securities Exchange market. However, the study was limited since it only focused on interest rate volatility and did not other factors in its model.

Mugambi and Okech (2016) conducted a study in Kenya which sought to determine the relationship between bank stock returns and macroeconomic variables. The study examined the following macroeconomic variables: GDP, inflation rate, interest rate, and exchange rate. The study collected secondary data from the year 2000 to 2015. Ordinary Least Squares and linear regression model was used to draw inference from the data collected. The findings of the study revealed that the following macroeconomic variables have a significant effect on the stock returns of banks: inflation, exchange rate, and interest rate. According to Mugambi and Okech (2016), there is a significant negative relationship between bank stock returns and interest rates. This is attributed to the fact that interest rate fluctuations have a negative effect on bank profitability which subsequently affects bank stock returns.

Obegi and Oluoch (2019) carried out a study which sought to determine the relationship between bank financial performance and price risk. In this case, price risk was measured using exchange rate risk, inflation, and interest rate risk. The study sourced secondary data from CBK reports dating 2013 to 2018. A time series regression model was utilized to draw inference from the data collected. The findings of the study revealed that price risk had there a significant effect on bank financial performance. According to Obegi and Oluoch (2019), interest rate had a positive none significant effect on bank profitability. Similarly, Ayub and Masih (2013) carried out a study whose findings revealed that there is no significant relationship between interest rates and Islamic bank stock prices.

However, various studies give contradictory findings. Lagat and Okendo (2016) carried out a study in Kenya which sought to determine the influence of interest rate volatility on the financial performance of banks. The study examined the banks listed at the NSE for the financial period 2006 to 2013. A multivariate linear regression model was utilized to draw inference from the secondary data collected. The findings revealed a weak positive relationship between fluctuations of bank interest rate and financial performance.

Similarly, Ngalawa and Ngare (2014) conducted a study whose overall objective was to determine the strategies Kenyan banks manage interest rate risk. The study examined 10 commercial banks listed at the Nairobi Securities Exchange for the period between 2008 and 2012. According to Ngalawa and Ngare (2014), the following are causes of interest rate risk: repricing risk, yield curve risk, basis risk, and optionality risk. The findings of their study revealed that a change of $2 \%$ in market interest rates could result in $0.4 \%$ change in income of the total assets of the bank.

Macharia (2013) conducted a study which sought to determine the extent to which the financial performance of banks in Kenya offering mortgage financing were influenced by the global financial crisis. The study adopted a descriptive form of research design. The population for the study was 330 managerial employees working for 10 commercial banks. Questionnaires were utilized as the data collection instrument for the study. Quantitative analysis was utilized to draw inference from the data collected. According to Macharia (2013), a unit rise in interest rate will result in a financial performance decrease of 0.425 by banks offering mortgage products. Consequently, the study recommends that interest rate fluctuations significantly affect the financial performance of financial institutions. 


\subsection{Conceptual Framework Independent Variable}

Dependent Variable

Price Risk:

- Residential Mortgage Interest Rate

Volatility

Figure 1. Conceptual Framework

The figure 1 presents the conceptual framework for the study. The independent variable is price risk while the dependent variable is the market returns of public mortgage originating firms in Kenya.

\section{Methodology}

The study adopted a descriptive form of research design. Descriptive research design was used to determine the effect of residential mortgage price risk on market returns of public mortgage originators in Kenya. In addition, a quantitative research approach was utilized to develop mathematical models which were used to validate the study's hypothesis. A census was conducted on the target population - 11 publicly listed mortgage originators in Kenya.

According to CBK (2018), 76.1 percent of mortgage lending in the year 2018 was done by six banks (five large peer banks and one medium sized bank). Consequently, Kenya's mortgage lending market is controlled by commercial banks. In addition, all of the 11 commercial banks listed at the NSE offer mortgages as one of their financial products. Consequently, the 11 publicly listed mortgage originating firms presented a suitable target population for the study. The study sourced its data from secondary sources: CBK bank supervision reports, and the NSE. Secondary data was sourced from the year 2009 to 2019.

A panel data regression model was utilized to determine the extent and degree to which residential mortgage price risk influences the market return for publicly listed mortgage originators in Kenya. Below is the representation of the model:

$$
\mathrm{Yi}=\beta 0+\beta 1 \mathrm{X} 1, \mathrm{t}++\varepsilon \mathrm{i}
$$

$\beta_{1}$ represent the specific beta coefficient. $X_{1}$ represents residential mortgage price risk. $\varepsilon_{\mathrm{i}}$ represents the error term in the model. $\beta 0$ represents the constant while Yi represents market return. Price risk was measured using a 3-point moving standard deviation of the annual residential mortgage interest rates. Price risk was measured using the formula illustrated below.

$$
S D=\frac{1}{3} \sum^{3} \sqrt{(i-\bar{I})^{2}}
$$

Market return was mis $\bar{a}$ tred using the ratio displayed below. Where $\mathrm{P} t$ is the current annual stock price, $\mathrm{P} t-1$ is the previous year stock price, and $R i$ is the market return.

$$
\boldsymbol{R}_{i}=\frac{\mathrm{p}_{t}-\mathrm{p}_{t-1}}{\boldsymbol{p}_{t-1}} \times 100 \%
$$

\section{Research Findings and Discussions}

\subsection{Descriptive Statistics}

Table 1 presents the descriptive statistic results for residential mortgage interest rates and market return for publicly

\begin{tabular}{|c|c|c|c|c|c|c|c|}
\hline & \multirow[b]{2}{*}{$\mathbf{N}$} & \multirow[b]{2}{*}{ Mean } & \multirow[b]{2}{*}{$\begin{array}{l}\text { Std. } \\
\text { Deviation }\end{array}$} & \multirow{2}{*}{$\begin{array}{l}\text { Skewness } \\
\text { Statistic }\end{array}$} & \multicolumn{3}{|c|}{ Kurtosis } \\
\hline & & & & & $\begin{array}{l}\text { Std. } \\
\text { Error }\end{array}$ & Statistic & $\begin{array}{l}\text { Std. } \\
\text { Error }\end{array}$ \\
\hline $\begin{array}{l}\text { Residential } \\
\text { Mortgage Rate }\end{array}$ & 121 & .2193 & .11195 & .507 & .220 & -.149 & .437 \\
\hline Market Return & 121 & .0905 & .04198 & .484 & .220 & .659 & .437 \\
\hline $\begin{array}{ll}\text { Valid } & \mathrm{N} \\
\text { (listwise) } & \end{array}$ & 121 & & & & & & \\
\hline
\end{tabular}
listed mortgage originating firms in Kenya.

Table 1: Descriptive Statistics

Table 1 presents the mean and standard deviation findings for residential mortgage interest rate as 0.2193 and 0.11195 respectively. This implies that the average residential mortgage interest rate for mortgage loans is $21.93 \%$. 
Table 1 further reveals the mean and standard deviation for the market returns of public mortgage originators as 0.0905 and 0.04198 respectively. This implies that the average market returns for public mortgage originators in $9.05 \%$. The standard deviation values for both statistics are relatively low which implies that data variation among the 11 mortgage originators was low. The findings further reveal a skewness of 0.507 and 0.484 with reference to residential mortgage interest rate and market returns frequency distribution. This implies that the residential mortgage interest rate and market returns frequency distributions do not significantly deviate away from a normal distribution. The findings further presented in Table 1 revealed kurtosis statistics of -0.149 and 0.659 for residential mortgage interest rate and market returns respectively.

Similar findings are propagated through empirical literature. For instance, Merab (2012) carried out a study which sought to determine the influence of mortgage financing on the financial performance of commercial banks in Kenya. The findings revealed commercial banks in Kenya charge an average of 19\% interest on mortgages. Similarly, Wambui (2013) conducted a study which sought to examine the relationship between volatility of interest rates and mortgage default rate. The study population constituted of 44 banks and 1 mortgage financing company. Study findings revealed that banks charged an interest rate of between $7.29 \%$ and $16.15 \%$ for the between 2008 and 2012.

\subsection{Correlational Analysis}

Table 2: Correlations between Study Variables

\begin{tabular}{lll}
\hline & Pearson Correlation & Market Returns \\
\hline \multirow{3}{*}{ Market Return } & Sig. (2-tailed) & 1 \\
& $\mathrm{~N}$ & 121 \\
& Pearson Correlation & $-.583^{* *}$ \\
Price Risk & Sig. (2-tailed) & .000 \\
& $\mathrm{~N}$ & 121 \\
\hline
\end{tabular}

**. Correlation is significant at the 0.01 level (2-tailed)

*. Correlation is significant at the 0.05 level (2-tailed)

The findings further presented in Table 2 revealed a moderate negative correlation of -0.583 between residential mortgage price risk and market returns for public listed mortgage originators. This suggests that the two study variables - residential mortgage price risk and market returns for public mortgage originating firms are moderately negatively correlated. This implies that they move in opposite directions.

Similarly, Kamweru and Ngui (2017) conducted a study which sought to determine the influence of interest rates on the growth of Kenya's real estate sector. Descriptive form of research design was adopted from the data collection process. The study collected data from 182 developers in Nairobi County. Findings revealed that there is a low negative relationship of -0.287 between interest rates and performance of the real estate industry. In the same vein, Ngumo (2012) conducted a study whose finding revealed a strong negative correlation of -0.722 between interest rates and financial performance of mortgage firms.

\subsection{Diagnostic Tests}

\subsubsection{Normality Test}

Gray (2016) argues that normality tests are carried out to ascertain whether or not the standardized residuals are significantly normally distributed. The test for normality in this case was measured using Kolmogov-Smirnov statistic and the Shapiro-Wilk test. The table 3 presents the results for the test for normality using the KolmogovSmirnov and Shapiro-Wilk tests.

\section{Table 3: Test of Normality}

\begin{tabular}{lllllll}
\hline & \multicolumn{7}{l}{ Kolmogorov-Smirnov } & \multicolumn{5}{l}{ Shapiro-Wilk } \\
\cline { 2 - 7 } & Statistic & df & Sig. & Statistic & df & Sig. \\
\hline Price Risk & .207 & 121 & .090 & .929 & 121 & .075 \\
Market Return & .227 & 121 & .067 & .884 & 121 & .064 \\
\hline
\end{tabular}

According to Gray (2016), a sig. value of more than 0.05 for the Kolmogorov-Smirnov test signifies normality in a distribution. From the results presented in Table 3 price risk and market return variables had a KolmogorovSmirnov sig value of 0.090 and 0.067 respectively. This is more than .05 which suggests that both price risk and market return have normal distributions. Gray (2016) postulates that a sig. value of more than 0.05 in the ShapiroWilk test reveals that data is normally distributed. On the contrary, a sig. value of below than 0.05 reveals that the data significantly deviates from a normal distribution. From the findings presented on Table 3, both price risk and market return have a Shapiro-Wilk sig. value of above 0.05 . This suggests that the data for the study variables have normal distributions. Consequently, the data collected fulfills and meets one of the assumptions of panel 
regression modeling - residuals should have normal distributions.

\subsubsection{Unit Root Test}

In order to determine stationarity, the study developed the hypothesis that data for the variable residential mortgage price risk was non-stationary. Table 4 presents the unit test results for the variable residential mortgage price risk. Table 4: Unit root test for Price Risk

\begin{tabular}{|c|c|c|c|c|}
\hline \multicolumn{3}{|c|}{ Dickey-Fuller test for unit root } & \multicolumn{2}{|c|}{ Number of obs $=$} \\
\hline & & \multicolumn{3}{|c|}{------- Interpolated Dickey-Fuller ------- } \\
\hline & Test & 1\% Critical & $5 \%$ Critical & $10 \%$ Critical \\
\hline & Statistic & Value & Value & Value \\
\hline $\mathrm{Z}(\mathrm{t})$ & -10.693 & -3.503 & -2.889 & -2.579 \\
\hline
\end{tabular}

MacKinnon approximate $\mathrm{p}$-value for $\mathrm{Z}(\mathrm{t})=0.0000$

From the findings presented, the MacKinnon critical value is 0.0000 . Consequently, we reject the null hypothesis - data for the variable price risk is non stationary. This implies that the data relating to price risk is stationery. Consequently, the data fulfils one of the assumptions of time series modelling.

\subsubsection{Autocorrelation Test}

A Durbin-Watson test was conducted to test for autocorrelation. The test of autocorrelation was conducted to measure the existence of pattern of error term observations which could affect regression results. Table 5 presents the autocorrelation test results.

\section{Table 5: Test for Autocorrelation}

\begin{tabular}{lccccc}
\hline Model & R & R Square & Adjusted R Square & $\begin{array}{l}\text { Std. Error of the Durbin-Watson } \\
\text { Estimate }\end{array}$ \\
\hline 1 & .839 & .703 & .693 & .03838 & 1.942 \\
\hline
\end{tabular}

a. Predictors: (Constant), Price Risk

b. Dependent Variable: Market Return

The Durbin-Waston test statistic as presented in Table 5 is 1.942. According to Pallant (2005), Durbin-Watson statistic test value ranges between zero and four. In addition, a rule of thumb is that test statistic values which range between 1.5 and 2.5 have acceptable levels of autocorrelation. Consequently, the panel regression model for the study had normal relative levels of autocorrelation.

\subsubsection{Hausman Test}

A Hausman test was conducted to determine the presence of endogenous regressors (predictor variable) in the regression equation. According to Baltagi (2012), the existence of endogenous regressors violates one of the assumptions of ordinary least squares which states that there should no correlation between the predictor variable and error term. The Hausman Speciation test further enabled the study to determine which panel model to utilize - random effects model or fixed effects model. In order to determine whether select between a fixed or random effects model, the study adopted a null hypothesis which stated that the study utilizes the fixed effects model (the unique errors are correlated with the regressors, the null hypothesis is they are not). From the findings, the null hypothesis - the study utilizes the fixed effects model - was rejected. Consequently, the alternative hypothesis was accepted. Therefore, the study adopted the Random Effect Panel Model (REM).

\subsection{Panel Regression Results}

Table 6 presents the bivariate regression results on the effect of residential mortgage price risk on the market returns of publicly listed mortgage originators. Table 6 reveals an R square value of 0.4529 between residential mortgage price risk and market returns of publicly listed mortgage originators. This suggests that $45.29 \%$ of variations of market returns for publicly listed mortgage originators is influence by residential mortgage price risk. 


\section{Table 6: Panel Model Modelling for the effect of Price Risk on Market Return}

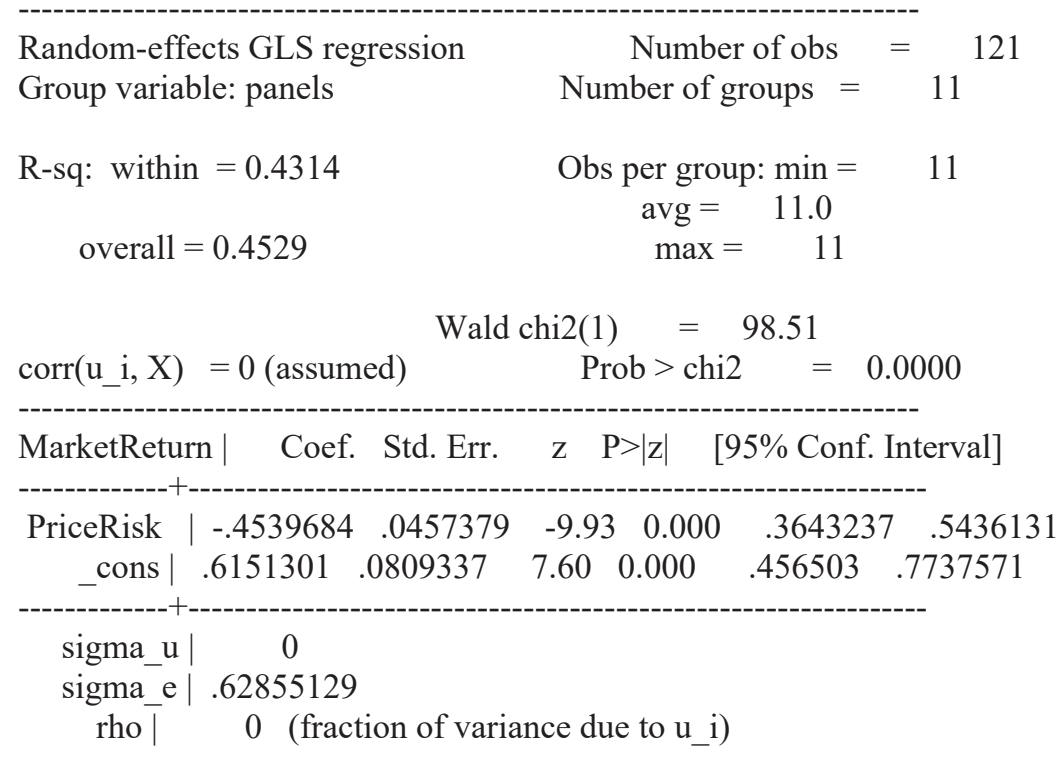

Table 6 further reveals a beta coefficient of -0.4539684 . This implies that a unit change in residential mortgage price risk will cause a decrease of 0.4539684 in market returns for public mortgage originators. Table 6 further reveals a $\mathrm{z}$ value of -9.93 with a p-significance value of .000 which is less than .05 . This suggests that price risk has a significant effect on the market returns of public mortgage originators. Thus, we reject the null hypothesis residential mortgage price risk has no significant effect on market returns of publicly listed mortgage originators in Kenya. Consequently, we accept the alternative hypothesis which states that residential mortgage price risk has a significant effect on the market returns of public mortgage originators.

Empirical literature reveals similar findings. For instance, Mugambi and Okech (2016) conducted a study in Kenya which sought to determine the relationship between bank stock returns and macroeconomic variables. Ordinary Least Squares and linear regression model was used to draw inference from the data collected. The study findings revealed that there is a significant negative relationship between bank stock returns and interest rates. Mugambi and Okech (2016) attribute this to the fact that interest rate fluctuations have a negative effect on bank profitability which subsequently affects bank stock returns.

In contrast, Ayub and Masih (2013) carried out a study whose findings revealed that there is no significant relationship between interest rates and Islamic bank stock prices. Similarly, Tran (2013) carried out a study whose findings revealed that interest rate volatility significantly influences bank stock returns and performance. In particular, long-term interest rates and returns of bank ordinary stocks are correlated positively.

In the same light, Kavwele, Ariemba and Evusa (2018) conducted a study which sought to determine the relationship between interest rate capping and bank performance. The study collected secondary data prior to and after Kenya enforced the law on interest capping. Data was analyzed through a multiple linear regression model. The findings of the study revealed a negative relationship between interest rate capping and bank performance.

Similarly, Macharia (2013) conducted a study which sought to determine the extent to which the financial performance of banks in Kenya offering mortgage financing were influenced by the global financial crisis. Quantitative analysis was utilized to draw inference from the data collected. The findings of the study revealed that a unit rise in interest rate will result in a financial performance decrease of 0.425 by banks offering mortgage products.

In contrast, Ngumo (2012) carried out a study whose findings revealed that mortgage interest rates have a positive significant effect on bank profitability. However, Ngumo notes that high mortgage interests positively influence bank profitability to a certain point; after which they can discourage borrowings. In the same vein, Lagat and Okendo (2016) carried out a study in Kenya which sought to determine the influence of interest rate volatility on the financial performance of banks. A multivariate linear regression model was utilized to draw inference from the secondary data collected. The findings revealed a weak positive relationship between fluctuations of bank interest rate and financial performance.

\section{Conclusion}

Price risk refers to the value decline of a portfolio or security (Cusatis \& Thomas, 2005). With reference to the mortgage industry, price risk is the adverse effect in the value of the mortgage commitment as a consequence of changes in mortgage rates (Shiller, 2012). This study sought to determine the influence of residential mortgage 
price risk on market returns of public mortgage firms in Kenya. From the findings, the average residential mortgage price risk for mortgage firms was $21.93 \%$ with a standard deviation of 0.11195 . This suggests that there is a degree of variation among mortgage originators when it comes to the interest rates they charge on mortgage products. The findings further revealed a negative correlation of -0.583 between residential mortgage price risk and market returns for public mortgage originators.

From data collection process of the study, the findings reveal an R square value of 0.4529 between residential mortgage price risk and market returns of publicly listed mortgage originators. This suggests that $45.29 \%$ of variations of market returns for publicly listed mortgage originators is influence by residential mortgage price risk. The findings further reveal a beta coefficient of -0.4539684 which implies that a unit change in residential mortgage price risk will cause a decrease of 0.4539684 in market returns for public mortgage originators. The findings further presented revealed a significance value of .000 which is less than .05 . This suggests that residential mortgage price risk has a significant effect on the market returns of public mortgage originators. Thus, the study rejected the null hypothesis.

\section{Recommendations}

From the findings, it was evident that residential price risk has a significant effect on the market returns of mortgage originators. It is suggested that mortgage originators to use derivative instruments and competitive interest rates in order to hedge against fluctuations in interest rates which effectively has an impact on their revenues.

\section{REFERENCES}

Agenor, P. R., \& Montiel, P. J. (2015). Development macroeconomics. (4 ${ }^{\text {th }}$ Ed.). Oxford: Princeton University Press.

Ahmed, A., Rehan, R., Chhapra, U., \& Supro, S. (2018). Interest rate and financial performance of Banks in Pakistan. International Journal of Applied Economics, Finance and Accounting, 2(1), 1-7.

Akenga, G. M., Olang, M. A., \& Galo, N. M. (2015). Effect of mortgage market risk on mortgage uptake: A case study of mortgage lenders in Kenya. Journal of Investment and Management, 4(6), 334-347.

Amarasinghe, M. (2015). Dynamic relationship between interest rate and stock price: Empirical evidence from Colombo Stock Exchange. International Journal of Business and Social Science, 6(4), 92-97.

Avallone, M. (2017). Why an interest rate hike will not stop the stock market rally. Retrieved September 19, 2017 , from <https:/www.forbes.com/sites/markavallone/2017/08/15/why- an-interest-rate-hike-will-not-stop-thestock-market-rally/\#6abcf2b77a98>.

Ayub, A., \& Masih, M. (2013). Interest rate, exchange rate, and stock prices of Islamic banks: A panel data analysis. Retrieved September 1, 2017, from <https://mpra.ub.unimuenchen.de/58871/1/MPRA paper 58871.pdf>.

Baltagi, B. (2012). Econometric analysis of panel data. New Jersey: John Wiley \& Sons.

Barth, J. (2009). The rise and fall of the US mortgage and credit markets: A comprehensive analysis of the market meltdown. New Jersey: John Wiley \& Sons.

Brener, A. (2020). Housing and financial stability: Mortgage lending and macroprudential policy in the UK and US. London: Routledge, Taylor \& Francis Group.

Burton, E., \& Shah, S. (2013). Behavioral finance: Understanding the social, cognitive, and economic debates. New Jersey: John Wiley \& Sons.

Burton, M., \& Brown, B. (2009). The financial system and the economy: Principles of money and banking. $\left(5^{\text {th }}\right.$ Ed.). New York: Routledge.

CBK. (2018). Bank supervision annual report 2018. Retrieved March 19, 2020, from $<$ https://www.centralbank.go.ke/uploads/banking_sector_annual_reports/1174296311_2 018\%20Annual\%20Report.pdf $>$.

Coleman, K. A. (2008). Impact of macroeconomics indicators on stock market performance: The case of the Ghana Stock Exchange. The Journal of Risk Finance, 9(4), 365-378.

Cusatis, P., \& Thomas, M. (2005). Hedging instruments and risk management: How to use derivatives to control financial risk in any market. New York: McGraw-Hill Professional.

Dhanani, A., Fifield, S., Helliar, C., \& Stevenson, L. (2008). The management of interest rate risk: Evidence from UK companies. Journal of Applied Accounting Research, 9(1), 52- 70.

Elton, J. E., Gruber, M. J., Brown, S. J., \& Goetzmann, W. N. (2009). Modern portfolio and investment analysis. New Jersey: John Wiley \& Sons.

Fama, E. (1970). Efficient capital markets: A review of theory and empirical work. Journal of Finance, 25(2), 383-417.

Gray, E. D. (2016). Doing research in the business world. London: Sage.

Juma, A. M., \& Atheru, G. (2018). Financial risks analysis and performance of commercial banks in Kenya. Journal of Finance and Accounting, 2(2), 76-95. 
Kamweru, E., \& Ngui, M. (2017). Effects of interest rates on the performance of real estate industry in Kenya: A case of Nairobi County. International Journal of Finance, 2(6), 35 -59.

Kavwele, D. T., Ariemba, J. M., \& Evusa, Z. (2018). Effect of interest rate capping on the financial performance of commercial banks in Kenya. International Journal of Business Management and Economic Research, 9(1), $1182-1190$.

Kigomo, J. (2016). Mortgage rates in Kenya: Implications for homeownership. International Academic Journal of Economics and Finance, 2(1), 31-40.

Lagat, C. C., \& Okendo, E. O. (2016). Financial performance of banks listed at the Nairobi Securities Exchange: The impact of interest rate fluctuations. International Journal of Current Research, 8(7), 35327-35331.

Liow, H. K., \& Huang, Q. (2006). Interest rate risk and time-varying excess returns for Asian property stocks. Journal of Property Investment \& Finance, 24(3), 188-210.

Macharia, E. W. (2013). The effects of global financial crisis on the financial performance of commercial banks offering mortgage finance in Kenya. International Journal of Economics and Finance, 1(2), 688-701.

Macharia, P. C., \& Wanyoike, D. M. (2016). Determinants of mortgage uptake from financial institutions in Nakuru town, Kenya. International Journal of Economics, Commerce and Management, 4(10), 569-598.

Mbulawa, S. (2015). Stock market performance, interest rate and exchange rate interactions in Zimbabwe: A cointegration approach. International Journal of Economics, Finance and Management, 4(2), 77-88.

Meng, X., \& Deng, X. (2013). Interest rate and foreign exchange sensitivity of bank stock returns: Evidence from China. Multinational Finance Journal, 17(1-2), 77-106.

Merab, D. A. (2012). The relationship between mortgage financing and financial performance of commercial banks in Kenya. Unpublished MBA dissertation. University of Nairobi, Nairobi.

Minny, M., \& Gormus, S. (2017). The impact of interest rate fluctuations on the participation bank profitability: Turkey case. International Journal of Islamic Economics and Finance Studies, 3(2), 55-65.

Molyneux, P., \& Vallelado, E. (2008). Frontiers of banks in a global economy. London: Palgrave Macmillan.

Mugambi, M., \& Okech, T. C. (2016). Effect of macroeconomic variables on stock returns of listed commercial banks in Kenya. International Journal of Economics, Commerce and Management, 4(6), 390-418.

Muharrami, A. S. (2015). Interest rate in Oman: Is it fair? Humanomics, 31(3), 330-343.

Muiruri, P. (2019). Why are Kenyans avoiding mortgages? Retrieved March 19, 2020, from $<$ https://www.standardmedia.co.ke/business/article/2001345824/why-are-kenyans- avoiding-mortgages>.

Mutegi, D. G., K'Akumu, O. A., Ondieki, E. (2019). Provision of down market urban housing in Kenya through strategic application of public private partnerships. Journal of Geography and Regional Planning, 12(2), 2033.

Mwaniki, C. (2013). HF lowers entry barriers to grow mortgage loans. Retrieved May 28, 2016, from $<\mathrm{http}$ :/www.businessdailyafrica.com/HF-lowers-entry-barriers-to-grow/539552/1978288/-/item/0/-/4p03mp/-/index.html >.

Ndung'u, A. T. (2012). The effect of interest rates volatility on stock market returns: Evidence from the Nairobi Securities Exchange. Unpublished MBA dissertation, University of Nairobi, Nairobi.

Ngalawa, J., \& Ngare, P. (2014). Interest rate risk management for commercial banks in Kenya. Journal of Economics and Finance, 4(1), 11-21.

Ngugi, B. (2018). Listed banks' drop in earnings per share linked to rate capping. Retrieved June 21, 2019, from $<$ https://www.businessdailyafrica.com/markets/capital/Listed- banks-drop-in-earnings-per-share/42594424396652-5kgvjo/index.html>.

Ngumo, L. W. (2012). The effect of interest rates on the financial performance of firms offering mortgages in Kenya. Unpublished MBA dissertation. University of Nairobi, Nairobi.

Nick (2016). Impact of rising interest rates on equity markets. Retrieved September 05, 2017, from $<$ https://www.tiaa.org/public/pdf/C37368_impact_of_rising_int_rates_on_equity_market s.pdf $>$.

Njiru, M. M., \& Moronge, M. (2013). Factors affecting growth of mortgage industries in Kenya: A case study of National Housing Corporation. International Journal of Social Sciences and Entrepreneurship, 1(7), 26-35.

Obegi, K. H., \& Oluoch, O. (2019). Effect of price risk on financial performance of commercial banks in Kenya. International Journals of Academics \& Research, 1(4), 176-184.

Oluwaseyi, E. O., Islam, A., Yusoff, W. S., \& Rahman, S. (2019). The effects of liquidity risk and interest-rate risk on profitability and firm value among banks in ASEAN-5 Countries. Journal of Reviews on Global Economics, 8, 337-349.

Omondi, D. (2016). Six banks struggle to achieve profitability. Retrieved June 21, 2019, from $<$ https://www.standardmedia.co.ke/article/2000197287/six-banks-struggle-to-achieve- profitability>.

Oyedele, A. (2017). The Fed just hiked rates for the $3^{\text {rd }}$ time - that has a history of signaling a 'major cyclical top for stocks'. Retrieved September 3, 2017, from <http://www.pulselive.co.ke/bi/finance/finance-the-fed-justhiked-rates-for-the-3rd-timeid6375247.html>. that-has-a-history-of-signaling-a-major-cyclical-top-for-stocks- 
Pallant, J. (2005). SPSS survival manual. Crows Nest: Allen \& Unwin.

Shiller, R. J. (2012). Finance and the good society. New Jersey: Princeton University Press.

Tran, H. (2013). Relationship between interest rate and bank common stock return: Evidence from the top 10 United States Banks and financial sector index. Retrieved September 5, 2017, from $<$ https://www.google.com/search?q=The+Relationship+between+Interest+Rate+and+Ba $\mathrm{nk}+$ Common+Stock + Return $\% 3 \mathrm{~A}+$ Evidence + from + the + to $+10+\mathrm{US}+$ Banks + and + Financia $1+$ Sector + Index\&oq $=$ The + Relationship + between + Interest + Rate + and + Bank + Common + St ock + Return $\% 3 \mathrm{~A}+$ Evidence + from + the + to $+10+$ US + Banks + and + Financial + Sector + Index \&aqs $=$ chrome..69i57.384860j0j7\&sourceid $=$ chrome\&ie $=$ UTF-8 $>$.

Vaz, J. J., Ariff, M., \& Brooks, R. D. (2008). The effect of interest rate changes on bank stock returns. Investment Management and Financial Innovations, 5(4), 221-236.

Wambui, S. N. (2013). The effect of interest rate volatility on mortgage default rate in Kenya. Unpublished Msc Finance dissertation. University of Nairobi, Nairobi.

Wicksell, K. (1936). Interest and prices. London: MacMillan.

World Bank. (2011). Developing Kenya's mortgage market. Washington: The International Bank for Reconstruction and Development. 